\title{
A Case of Pneumosinus Dilatans Presenting with Atypical Headache
}

\section{Atipik Baş A ̆grısı ile Başvuran Pnömosinüs Dilatans Olgusu}

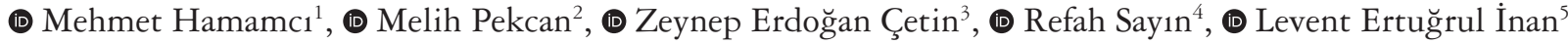

${ }^{1}$ Ardahan State Hospital, Clinic of Neurology, Ardahan, Turkey

${ }^{2}$ Ardahan State Hospital, Clinic of Radiology, Ardahan, Turkey

${ }^{3}$ Ardahan State Hospital, Clinic of Otorhinolaryngology, Ardahan, Turkey

${ }^{4}$ Ufuk University Faculty of Medicine, Department of Neurology, Ankara, Turkey

${ }^{5}$ Bozok University Faculty of Medicine, Department of Neurology, Yozgat, Turkey

Keywords: Headache, pneumosinus dilatans, high altitude

Anahtar Kelimeler: Baş ağrısı, pnömosinüs dilatans, yüksek rakım

\section{Dear Editor,}

A 22-year-old male patient residing at a high altitude presented to our clinic on the second day of having headache symptoms after flying back to his home following living at a low altitude center for 1 month. He stated that he had symptoms, including headache, during the flight.

The patient reported having a severe headache [visual analogue scale (VAS): 9], which started after the flight, it occurred twice a day and lasted for about 1 minute with a sensation of pressure on both sides of the head and an increase in head weight. Other than that, he had no other symptoms.
His medical history and family history were non-specific, except that he lived in a region with high altitude and cold climates. The patient's VAS was reported as 9. There was no evidence of meningeal irritation. No pathology was found in the fundus examination. There was no nasal discharge. The blood tests were within normal limits and a computed brain tomography (CT) examination was planned for the differential diagnosis of atypical headache, including suspected subarachnoid hemorrhage and sinusitis. Diffuse enlargement of the sinuses was detected in CT (Figures 1A, 1B, 1C, 1D). There was hyperpneumatization in the paranasal sinuses. There was no mass lesion in the sinuses

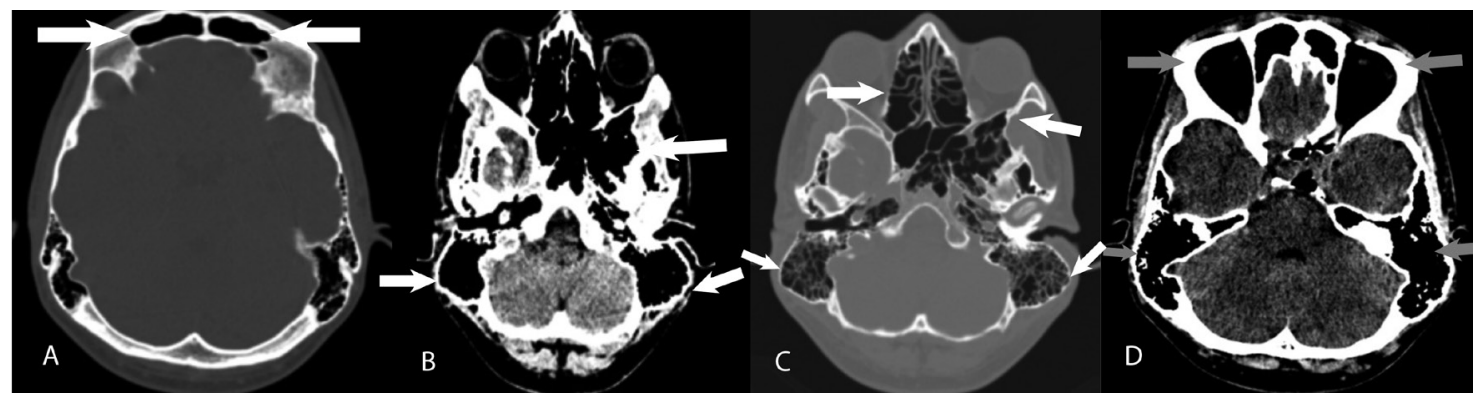

Figure 1. A) Axial computed tomography in bone window. B) Axial computed tomography in parenchyma window. C) Axial computed tomography in bone window. D) Axial computed tomography in parenchyma window. Axial computed tomography images demonstrate hyperpneumatisation (more obvious on the left) in bilateral mastoid cells, ethmoid cells, frontal sinuses and sphenoid sinuses.

Address for Correspondence/Yazışma Adresi: Mehmet Hamamcı MD, Ardahan State Hospital, Clinic of Neurology, Ardahan, Turkey Phone: +90 5062985757 E-mail: drmehmetmehmet@gmail.com ORCID ID: orcid.org/0000-0001-7100-3952

Received/Geliş Tarihi: 09.11.2017 Accepted/Kabul Tarihi: 20.04.2018

${ }^{\circ}$ Copyright 2018 by Turkish Neurological Society

Turkish Journal of Neurology published by Galenos Publishing House. 
or pathologic findings in the mucosa. Brain magnetic resonance imaging (MRI), brain magnetic resonance angiography (MRA) and magnetic resonance venography (MRV) were performed for additional pathologies or exclusion of mass lesions. No meningioma or arachnoid cysts were found in the brain MRI. No pathology was detected in the brain MRA and MRV examinations of the patient. With these findings, analgesic treatment was initiated and the patient was followed up. After five days, the patient stated that his headache had relieved and he had no symptoms after one month of a drug-free follow-up period.

Paranasal sinuses are spaces filled with air and surrounded by mucosa, which are formed by the formation of a layer in the adjacent skull and maxilla by the mucosa in the nasal cavity. Pneumosinus dilatans (PSD) is a term that only refers to the abnormal enlargement of air-containing paranasal sinuses. Direct X-ray, CT, and MRI are used in the diagnosis of PSD. The diagnostic criteria include enlargement of air cells or the whole or part of the sinus, presence of only air in the sinus cavity, and outward expansion of the sinus wall. Most cases reported in the literature involve the frontal sinuses (1).

Although PSD pathophysiology is not clearly understood, factors such as developmental, inflammatory, and obstructive mechanisms are thought to play a role. Some theories suggest that the air pressure inside the sinus cannot be balanced with the environment, thus trapping the air inside the sinus under high pressure, and leading to sinus expansions $(1,2)$.

In the literature, association with meningioma and arachnoid cyst has been reported, and idiopathic PSD has rarely been reported $(1,3)$. Idiopathic PSD is commonly caused by barotrauma. It can be aggravated by valsalva maneuvers such as coughing, sneezing, and mountain climbing, airplane trips, and tube diving (1). It is usually non-symptomatic and incidentally detected on direct X-ray, CT or MRI examinations. The symptoms of patients with PSD are mainly cosmetic related, ocular changes, ptosis, and headache. Among them, headache is the most common cause of admission (4).
Babl et al. (5) reported a case of PSD in an 11-year-old girl who presented with occipital burst headache after a cough period.

High altitude, cold weather and airplane trips were determined as predisposing factors in the etiology of this case. We found it worthwhile to present a patient with idiopathic PSD who presented with atypical headache in this article.

Ethics

Informed Consent: Consent form was filled out by participant. Peer-review: Internally peer-reviewed.

\section{Authorship Contributions}

Surgical and Medical Practices: M.H., Concept: M.H., M.P., Z.E.Ç., Design: M.H., M.P., Z.E.Ç., R.S., L.E.İ., Data Collection or Processing: M.H., M.P., Analysis or Interpretation: M.H., M.P., Z.E.Ç., R.S., L.E.İ., Literature Search: M.H., M.P., Z.E.Ç., R.S., L.E.İ., Writing: M.H., L.E.İ.

Conflict of Interest: No conflict of interest was declared by the authors.

Financial Disclosure: The authors declared that this study received no financial support.

\section{References}

1. Lee JS, Park YS, Kwon JT, Suk JS. Spontaneous Pneumocephalus Associated with Pneumosinus Dilatans. J Korean Neurosurg Soc 2010;47:395-398.

2. Som PM, Sachdeu VP, Biller HF. Sphenoid sinus pneumocele: report of a case. Arch Otolaryngol 1983;109:761-764.

3. Parizel PM, Carpentier K, Van Marck V, et al. Pneumosinus dilatans in anterior skull base meningiomas. Neuroradiology 2013;55:307-311.

4. Appelt EA, Wilhelmi BJ, Warder DE, Blackwell SJ. A rare case of pneumosinus dilatans of the frontal sinus and review of literature. Ann Plast Surg 1999;43:653-656.

5. Babl FE, Arnett AM, Barnett E, Brancato JC, Kharasch SJ, Janecka IP. Atraumatic pneumocephalus: a case report and review of the literature. Pediatr Emerg Care 1999;15:106-109. 